\title{
THE INFLUENCE OF DEBT TO EQUITY RATIO, CURRENT RATIO, AND NET PROFIT MARGIN ON STOCK PRICE
}

(Empirical Study: In companies listed on the Indonesia Stock Exchange 2017-2019)

\author{
Garin Pratiwi Solihati \\ Faculty Economics and Business, Universitas Mercu Buana
}

Article DOI: $\underline{\text { https://doi.org/10.36713/epra8160 }}$

DOI No: 10.36713/epra8160

\begin{abstract}
Banking companies are increasingly active in stock trading as seen from the increase in the number of banks listed on the IDX. Several previous studies still yielded mixed results, so researchers are interested in conducting research with the title "The Effect of Debt To Equity Ratio (DER), Current Ratio, and Net Profit Margin (NPM) on Stock Prices (Empirical Study: In Banking Companies Listed on the Indonesia Stock Exchange in 2017-2019). This study is to determine the effect of Debt to Equity Ratio (DER), Current Ratio (CR) and Net Profit Margin (NPM) on stock prices. The object of this research is banking companies listed on the Indonesia Stock Exchange (IDX) for the 2017-2019 period. The sampling method used was purposive sampling. The data used in this research is secondary data. Data analysis was performed using descriptive statistical analysis tests, classical assumption tests, model suitability tests and hypothesis testing.

The results of this study are expected to show that there is a significant influence between Debt to Equity Ratio (DER), Current Ratio (CR) and Net Profit Margin (NPM) on stock prices. The target output of this research is in the form of international journal publications

KEYWORD: Debt to Equity Ratio, Current Ratio, Net Profit Margin, Stock Price
\end{abstract}

\section{INTRODUCTION}

In article 4 of the Banking Act 1992, the objective of banking is to support the implementation of national development in the context of increasing equity, economic growth and national stability towards improving the welfare of the people at large.

The current phenomenon is that the global debt rating agency, Moody's, calls Bank RI the most vulnerable to share prices. Moody's, in his latest research on September 30, 2019, said that the risk of banking in the Asia Pacific region will increase in line with the weakening ability of corporate debt repayments. The decline in corporate debt payments fell due to slow economic growth, rising trade war tensions and geopolitics. On the other hand, the domestic political situation is still unstable due to student demonstrations voicing their various demands (cnbcindonesia.com, 2019). Another phenomenon currently occurring is that Bank Indonesia has lowered the down payment regulation through the Loosening Loan to Value policy, both for motor vehicle loans and property loans. This provision will be effective starting December 2, 2019. This will have a positive impact on the banking sector because banks are providers of both automotive and property loans. If the down payment falls, the possibility of credit demand becomes more stretched. The projected improvement in credit performance makes these banking stocks more attractive or attractive to investors (cnnindonesia.com, 2019).

One of the factors that influence stock prices is the Debt To Equity Ratio (DER). DER is also known as the ratio that looks at the company's debt ratio, which is obtained from the ratio of total debt divided by total equity. The lower the better because it is safe for creditors during liquidation. For companies, the amount of debt should not exceed their own capital so that the fixed burden is not too high. A low DER will increase the positive response from the market and the better the company's ability to pay long-term obligations because the risk arising from the use of funding originating from debt will decrease, so that shares will rise. Therefore, DER has a negative effect on stock prices (Brigham and Houston, 2006: 104). This theory is supported by research by Stella (2009), Putu and Suaryana (2013) and Asmirantho (2014) which state that DER has a negative effect on stock prices. 
Another factor that affects stock prices is the Current Ratio. Current Ratio is a ratio that compares the accounts of current assets and current liabilities in order to determine the company's ability to pay off its shortterm liabilities. The increasing of this ratio will give a positive signal to the owner of the company that the company has a good ability to pay off obligations that must be paid immediately. Investors will eventually respond to this positive signal and lead to an increase in share prices. Research conducted by Rachman (2012) found that the Current Ratio partially affects stock prices in manufacturing companies Clarensia et. al. (2018) found that the Current Ratio has a positive effect on stock prices in manufacturing companies. The same results are also shown by research conducted by stocks (Pouraghajan, et al 2013) with path analysis that directly affects the current ratio of stock market prices.

The last factor in this study that is thought to have an effect on stock prices is Net Profit Margin (NPM). NPM is the ratio used to show the company's ability to generate net profit after tax. The greater the NPM value, the higher the company's ability to generate net income. With the company's ability to generate higher net income, it is expected to be able to have a positive effect on stock prices (Ang, 1997). In Rescyana's (2012) research, high NPM signals the company's success in carrying out the mission of its owner. Companies that are able to generate profits will influence investors or potential investors to invest. Investors will be willing to buy shares at a higher price if they estimate the company's NPM level will increase, and vice versa investors are not willing to buy shares at a high price if the company's NPM value is low. In contrast to the research of Prameswari (2014) which found that NPM had no and significant effect on stock prices.

Based on the description above, several previous studies have yielded mixed results, so researchers are interested in conducting a study entitled "The Effect of Debt To Equity Ratio (DER), Current Ratio, and Net Profit Margin (NPM) on Stock Prices (Study Empirical: In Banking Companies Listed on the Indonesia Stock Exchange 2017-2019). Researchers chose the banking sector because banking stocks are the most popular stocks, even though in mid-1997 and during the 2008 global financial crisis the banking sector had fallen and experienced a decline in performance (Amanda and Wahyu, 2013). Over time, the banking sector was able to prove its existence in performance and achieving good results so that investors were attracted to buy its shares again. Even some banking stocks that go public on the IDX are included in the most active stock category in the LQ 45 Index. In addition, banking companies are increasingly active in stock trading as seen from the increase in the number of banks listed on the IDX

\section{Formulation of Problem}

Based on the background that has been described, the problem formulations in this study are:

1. Does the Debt To Equity Ratio (DER) affect stock prices?

2. Does Current Ratio affect stock prices?

3. Does Net Profit Margin (NPM) affect stock prices?

\section{LITERATURE REVIEW}

\section{Signalling Theory}

Signal theory underlies this research, signaling theory originated from the writings of George Akerlof in his 1970 work "The Market for Lemons", which introduced the term asymmetric information (information asymmetry). Akerlof (1970) studied the phenomenon of imbalance of information regarding product quality between buyers and sellers by testing the used car market. Signal theory is used to explain that financial reports are used to provide positive signals (good news) and negative signals (bad news) to the wearer. According to Brigham and Housten (2011) cues or signals are actions taken by company management that form instructions for investors about how management views the company's prospects.

Siganalling theory states that investment spending gives a positive signal about the company's future growth, thereby increasing stock prices as an indicator of company value (Brigham and Houston, 2011). An increase in debt can also be interpreted by outsiders about the company's ability to pay its obligations in the future or a low business risk, so that additional debt will give a positive signal. This is because companies that increase debt can be seen as companies that are confident about the company's prospects in the future (Brigham and Houston, 2011).

Every action containing information is the basic principle of signal theory, this is due to the presence of asymmetric information. Signal theory explains that managers provide a number of signals to reduce information asymmetry (Wibowo, 2017). Information published as an announcement will provide a signal for investors in making investment decisions. If the announcement contains a positive value, it is expected that the market will react when the announcement is received by the market (Jogiyanto, 2009). Financial reports are a type of information issued by a company that is a signal for parties outside the company. Information in financial reports relates to accounting information, namely information related to company finances such as financial reports and non-accounting information that is not related to financial statements. 


\section{Stock Exchange}

The capital market is a meeting place between sellers and buyers with risk of profit and loss as well as a means for companies to increase long-term funding needs by selling stocks or issuing bonds (Jogiyanto, 2010: 29). Meanwhile, according to Husnan (2001: 3) formally the capital market can be defined as a market for various long-term financial instruments that are commonly traded either in the form of debt or equity issued by the government and companies.

The capital market has an important role in the economy, especially in allocating public funds. The capital market is a means for companies to increase long-term needs by selling stocks or issuing bonds. The capital market also functions as a means of allocating productive funds to move funds from lenders to borrowers.

\section{Stock Price}

Shares, namely proof of participation or participation in a limited liability company for the company concerned. Stock is a form of equity capital or proof of ownership position in a company. Many stocks are not traded because they are too small or fully controlled by the family. Shares that can be used as a vehicle for investment are those known as issuances that are publicly traded and bought and sold on the open market (Umam \& Sutanto, 2017). Shares can also be defined as proof or certificate of ownership or an entity against the company that issues the securities, which can also be interpreted as the participation of investors as investors in a company, so that they have a claim right on the company's income and assets.

According to Sunariyah (2011: 127), share prices can be divided into 3, namely:

a. Nominal Price, is the value set by the issuer to value each share issued. The nominal price depends on the issuer's wishes.

b. Initial Price, is the price before the share price is listed on the stock exchange. The initial price depends on the agreement between the issuer and the underwriter. This initial price is used to determine the basic value in the calculation of the stock price index.

c. Market Price, is the selling price of shares between one investor and another after being recorded on the stock exchange. Market prices depend on the forces of supply and demand in the secondary market. Market price is the easiest price to determine because it is the price of a share in the current market or if the market is closed, the market price is the closing price.

\section{Debt to Equity Ratio (DER)}

Debt to Equity Ratio (DER) is a measuring tool for calculating the leverage ratio. The leverage ratio is a measure of the company's financing from debt sources which will have an impact on fixed liabilities or expenses. Thus the debt ratio (leverage) is a measure of how much the company is financed from the debt element, and how much is the company's ability from the results of the company's operations to pay off the interest and / or principal on the loan. Meanwhile, the definition of Debt to Equity Ratio (DER) itself is the ratio between total debt and total equity in a company which gives an overview of the ratio of total debt to the company's own capital (equity). The greater this ratio, the greater the role of debt in financing company assets and vice versa (Sitanggang, 2014: 23).

Zulfikar (2016) explains that the Debt to Equity Ratio or often called the leverage ratio is a measure of how much the company's interest is financed by debt compared to existing capital. From the opinion regarding the Debt to Equity Ratio (DER), it means that the higher the Debt to Equity Ratio (DER), the higher the financing made by the company to run its company. The formula used in calculating the Debt to Equity Ratio (DER) according to Sitanggang (2014: 24):

\section{Current Ratio}

$$
\text { DER }=\frac{\text { Total Payable }}{\text { Capital }}
$$

Current Ratio is one of the most commonly used ratios to measure the liquidity or ability of a company to meet short-term obligations without facing difficulties. Syamsuddin (2016: 43) states that "Current ratio is one of the most frequently used financial ratios. The level of current ratio can be determined by comparing current assets with current liabilities ". The greater the current ratio, the higher the company's ability to meet its short-term obligations.

Kasmir (2018: 134) states that "the current ratio is a ratio to measure the company's ability to pay short-term obligations or debts that are due immediately when they are collected as a whole". Based on some of the opinions above, it can be concluded that the current ratio is one of the liquidity ratios that shows the level of company liquidity in relation to the company's ability to pay its short-term debt as seen from the comparison of current assets and current liabilities of the company.

Calculation of current ratio (CR) or current ratio is as follows: 


$$
C R=\frac{\text { Current Asset }}{\text { Current Payable }}
$$

\section{Net Profit Margin (NPM)}

Net Profit Margin (NPM) is a measuring tool for calculating the profitability ratio. The profitability ratio aims to measure the effectiveness of management which is reflected in the return on investment through company activities, or in other words, to measure overall company performance and efficiency in managing liabilities and capital (Sugiono and Untung, 2016: 66). Meanwhile, the definition of Net Profit Margin (NPM) itself is a ratio that measures how much the company's net profit from each sale, meaning that it has paid attention to operating costs, interest and corporate taxes. The higher this ratio, it shows that the company has a high margin from each sale against all costs, interest and taxes that are calculated by the company (Sitanggang, 2014: 29).

Kasmir (2012: 199) explains that Net Profit Margin (NPM) is one of the ratios used to measure the profit margin on sales. The method of measuring this ratio is to compare net income after tax with net sales. From the opinion regarding the Net Profit Margin (NPM), it means that the higher the Net Profit Margin (NPM), the more investors like the company because it shows that the company gets good results that exceed the cost of goods sold (Oktania, 2018). The formula used in the calculation of Net Profit Margin (NPM) according to (Sitanggang, 2014: 29):

$$
N P M=\frac{\text { Net Profit }}{\text { Sales }}
$$

\section{Previous Research}

Nur'aidawati (2018), her research entitled "The Effect of Current Ratio (CR), Total Asset Turn Over, Debt to Equity Ratio (DER), Return On Assets (ROA) on the stock prices of the ten largest banks listed on the Indonesia Stock Exchange period. 2011-2015 ". The results showed that the Current Ratio (CR) variable had a negative and no significant effect on stock prices. Total Asset Turn Over (TATO) has a positive and insignificant effect on stock prices. Debt to Equity (DER) has a negative and insignificant effect on stock prices. Return on Assets (ROA) has a positive and significant effect on stock prices.

Cahyaningrum and Antikasari (2017), their research entitled "The Effect of Earning Per Share, Price To Book Value, Return On Asset, and Return On Equity Against Changes in Financial Sector Stock Prices in 2010-2014". The results of his research show that the variables Earning Per Share, Price To Book Value, Return On Assets and Return On Equity have a positive and significant effect on stock prices.

Hutasoit et al (2019), his research entitled "The Effect of Net Profit Margin, Non Performing Loans and Capital Adequacy Ratio on Stock Prices in Banking Companies Listed on the Indonesia Stock Exchange for the 2014-2017 Period". The results of his research show that the Net Profit Margin variable partially has no and insignificant effect on stock prices. Partially Non Performing Loans have a positive and significant effect on stock prices. The Capital Adequacy Ratio partially has no and insignificant effect on stock prices.

Watung and Ilat (2016), their research entitled "The Effect of Return On Assets (ROA), Net Profit Margin (NPM), and Earning Per Share (EPS) on Stock Prices in Banking Companies on the Indonesian Stock Exchange 2011-2015. The results of his research show that the variables Return On Asset, Net Profit Margin and Earning Per Share partially have a significant effect on stock prices.

\section{Thought Framework}

Based on the periodization chosen in this study and on the previous description, the theoretical framework of this study is described as follows:

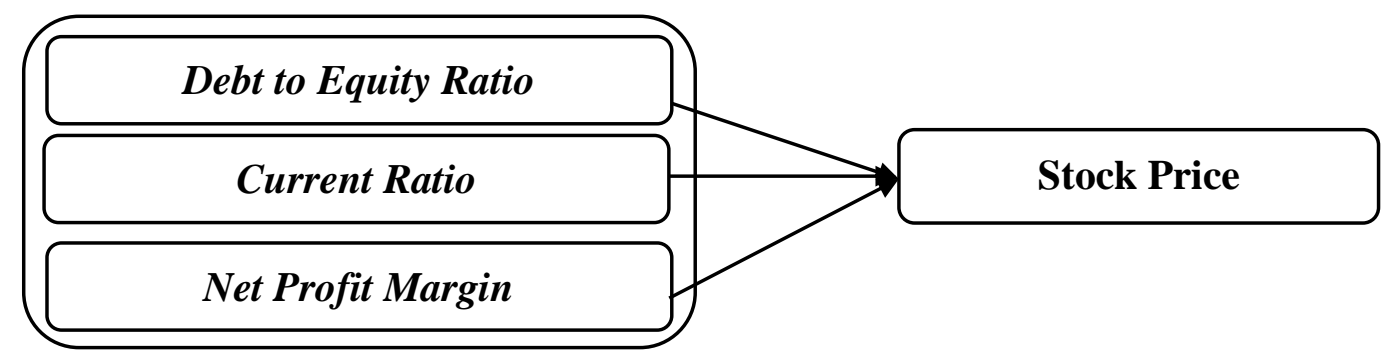

Figure 1. Thought Framework 


\section{Research Hypothesis}

H1: Debt to Equity Ratio affects stock prices

H2: Current Ratio affects stock prices

H3: Net Profit Margin affects stock prices

\section{RESEARCH METHOD}

This research is a causal research, namely research that aims to test hypotheses about the effect of one or more variables on other variables. Researchers use this research design to provide empirical evidence about the effect of the Debt to Equity Ratio (DER), Current Ratio, and Net Profit Margin (NPM) on stock prices.

\section{Variable Operation}

The variables used in this study are the independent variable and the dependent variable. The independent variables in this study are Debt to Equity Ratio (DER), Current Ratio (CR) and Net Profit Margin (NPM). The dependent variable in this study is the stock price. The scale of the measurement of the independent variables and the dependent variable in this study is to use a ratio scale.

The dependent variable $(\mathrm{Y})$ or the dependent variable is a variable that is influenced by other variables (in this case the independent variable) (Timotius, 2017: 50). In this study the dependent variable is the stock price. The independent variable $(\mathrm{X})$ or the independent variable is a variable that affects other variables (Timotius, 2017: 50). In this study the independent variables are Debt to Equity Ratio (DER), Current Ratio and Net Profit Margin (NPM).

\section{Population and Research Sample}

In accordance with the research to be studied, namely the effect of Debt to Equity Ratio, Current Ratio, and Net Profit Margin on Stock Prices. So in this study the population taken is the financial statements of banking companies listed on the Indonesia Stock Exchange (IDX) from 2017 to 2019. The data analyzed in this study are quantitative secondary data obtained from the publication of financial reports by the Indonesia Stock Exchange ( IDX). After the researchers examined the website www.idx.co.id, it was found that there were 46 companies engaged in banking.

The method of sampling is to use purposive sampling method which is part of the non-probability sampling method with the aim of getting a representative sample in accordance with predetermined criteria. The population of data to be processed in this study is from 46 banks in Indonesia, Debt to Equity Ratio (DER), Current Ratio (CR), and Net Profit Margin (NPM) data in 3 years, from 2017-2019 for each. The independent variable is 138 data on its effect on stock prices.

\section{Data Analysis Method}

Data analysis was performed using the SPSS 26 program including the following analysis:

1. Descriptive Statistical Test

2. Classical Assumption Test which consists of Normality Test, Multicolonierity Test, Heteroscedasticity Test, and Autocorrelation Test

3. Model Feasibility Test consisting of Analysis of the Coefficient of Determination (R2 test), Simultaneous Regression Coefficient Test ( $\mathrm{F}$ test) and Partial Test ( $\mathrm{t}$ test).

\section{Data Analysis Results}

Data analysis was performed using SPSS 23 . The analytical methods used in this study included analysis of descriptive statistics and multiple regression analysis. 


\section{Descriptive Statistics}

Table 1. Descriptive Statistics

Descriptive Statistics

\begin{tabular}{|l|c|c|c|c|c|}
\hline & $\mathrm{N}$ & Minimum & Maximum & Mean & Std. Deviation \\
\hline DER & 175 & 2,45 & 18,21 & 6,7463 & 2,69809 \\
CR & 175 & .0056 & 2.6358 & .75684 & .0823819 \\
NPM & 175 & $-123,75$ & 54,89 & 8,1934 & 21,52439 \\
Stock Price & 175 & 15,18 & 33425,00 & 2163,4434 & 4169,83832 \\
Valid N (listwise) & 175 & & & & \\
\hline
\end{tabular}

The sample in this study amounted to 175 data from 35 banking companies listed on the Indonesia Stock Exchange (IDX) for the 2014-2018 period. The variables studied are Debt to Equity Ratio (DER), Earning Per Share (EPS) and Net Profit Margin (NPM) on stock prices.

1. The variable Debt to Equity Ratio (DER) with the lowest value of 2.45 is data owned by Bank of India Indonesia Tbk (BSWD) in 2018, this is because BSWD in 2018 experienced a share divestment so that the DER generated is very small compared to another year. While the highest score of 18.21 was owned by the Regional Development Bank of Banten Tbk (BEKS) in 2015, this was due to BEKS in 2015 conducting a rights issue so that the DER generated was very large compared to other years. The average value (mean) of DER is 6.7463 , which means that every Rp. 1 capital in the company is used to pay off the total debt of Rp. 6.7463. While the standard deviation value is 2.69809 which is smaller than the average value so that it shows the low fluctuation of DER data during the observation period.

2. The variable Current Ratio (CR) with the lowest value of 0.0056 is data owned by Bank of India Indonesia Tbk (BSWD) in 2016, while the highest value of 2.6358 is owned by Bank Central Asia Tbk (BBCA) in 2018. The higher the level of liquidity, then the company's performance is considered to be getting better. Companies with high liquidity ratios are usually easier to get financial assistance from other parties. The mean value (mean) of CR is .75684. Meanwhile, the standard deviation value is .0823819 which is smaller than the average value, thus indicating the low fluctuation of DER data during the observation period.

3. Variable Net Profit Margin (NPM) with the lowest value -123.75 is data owned by Bank of India Indonesia Tbk (BSWD) in 2016, this is due to BSWD in 2016 experiencing a decline in interest income and other operating income, In addition, other operating expenses have increased so that the NPM generated is very small compared to other years. While the highest value of 54.89 was owned by Bank Woori Saudara Indonesia 1906 Tbk (SDRA) in 2014, this was due to SDRA in 2014 merging between PT Bank Woori Indonesia and PT Bank Himpunan Saudara 1906 Tbk, after the merger experienced an increase in net profit so that the resulting NPM is very large compared to other years. The average value (mean) of NPM is 8.1934, which means that the average of companies in this sector for five years of net sales that are able to generate net profit is 8.1934. While the value of the standard deviation is 21.52439 which is greater than the average value so that it shows the high fluctuation of NPM data during the observation period.

4. Stock Price variable with the lowest value of 15.18 is data owned by the Regional Development Bank Banten Tbk (BEKS) in 2014, this is because BEKS since 2014 has often experienced losses due to poor company performance which causes investor interest to decrease so that the stock price yield is very small compared to other years. While the highest value of 33425.00 was owned by Bank Central Asia Tbk (BBCA) in 2018, this was due to BBCA in 2018 making a profit because the company's performance was good which caused it to be in great demand by investors so that the resulting share price was very large compared to other years. . The average value (mean) of stock prices is 2163.4434, which means the ability of companies in this sector for five years to be able to produce an average share price of Rp. 2163.4434 on the Indonesia Stock Exchange. and a standard deviation of 4169.83832 which is greater than the average value, thus indicating the high fluctuation of stock price data during the observation period.

\section{Classic Assumption Test}

The classic assumption test is carried out so that the regression model in the research is significant and representative. In the multiple regression analysis, it is necessary to avoid any standard assumption deviation so that problems do not arise in its use. The basic assumption is that the data is normally distributed; there is no heteroscedasticity, multicollinearity, and autocorrelation. Based on the normality test in this study, the Asymp value model. Sig. (2tailed) $=0.110$, then according to the provisions of $0.110>0.05$, the residual 
value is normal. Then the data in the model can be said to be normally distributed. Multicollinearity test which shows that the VIF value is below 10 , and the tolerance value is above 0.10 . From the results of these tests, it can be concluded that the regression model does not have multicollinearity problems. Heterokedatisitas test shows that there was no heteroscedasticity. This can be seen from the probability of its significance (Sig. Value) on each independent variable above the $5 \%$ confidence level or 0.05 . So it can be concluded that the regression capital does not contain heteroscedasticity. The autocorrelation test in this study used the autocorrelation test using the Durbin-Watson (DW) test. The results of the autocorrelation test data obtained no positive or negative autocorrelation, or it can be concluded that there is no autocorrelation.

\section{Hypothesis Testing Results}

Determinant Coefficient Test Results $\left(\mathbf{R}^{2}\right)$

According to Ghozali (2018: 97), the coefficient of determination essentially measures how far the model's ability to explain variations in the dependent variable. The ratio of determination aimed at $\mathrm{R}^{2}$ from the regression model is used to determine the dependent variable that can explain the magnitude of the variability of the dependent variable. The coefficient of determination is 0.564 or $56.4 \%$. This shows that the variation of stock price $56.4 \%$ is influenced by the NPM, DER, and CR variables. Whileother factors outside the model influence the remaining 43,6\% (100-56.4\%).

\section{Model Feasibility Test Results (Test F)}

According to Ghozali (2018: 98), F statistical test is basically to show whether all independent variables are included.

ANOVA $^{\mathrm{a}}$

\begin{tabular}{|c|c|c|c|c|c|c|}
\hline & Model & Sum of Squares & Df & Mean Square & $\mathbf{F}$ & Sig. \\
\hline \multirow[t]{3}{*}{1} & Regression & 1705849781,091 & 3 & 568616593,697 & 73,685 &, $000^{\mathrm{b}}$ \\
\hline & Residual & 1319584193,847 & 171 & 7716866,631 & & \\
\hline & Total & 3025433974,938 & 174 & & & \\
\hline
\end{tabular}

a. Dependent Variable: Stocks_price

b. Predictors: (Constant), NPM, DER, CR

Based on the table, it is known that the calculated $F$ value of 73,685 with a probability of $0,000<0.05$; this indicates that the model used in this study is feasible. So in this regression model, it can be concluded that the variables of Net Profit Margin, Debt to Equity Ratio and Current Ratio, affect Stocks Price

\section{Significance Test Results for Individual Parameters (Statistical Test t)}

The statistical t-test shows how far the influence of one explanatory or independent variable individuallyin explaining the variation of the dependent variable. Tests carried out using a significance level of $0.05(5 \%)$. If the significance value is below 0.05 , simultaneously, the independent variable has a significant effect on thedependent variable (Ghozali, 2016: 97). T statistical test results are as follows:

\section{Coefficients $^{\mathrm{a}}$}

\begin{tabular}{|c|c|c|c|c|c|c|}
\hline \multirow{2}{*}{\multicolumn{2}{|c|}{ Model }} & \multicolumn{2}{|c|}{ Unstandardized Coefficients } & \multirow{2}{*}{$\begin{array}{c}\begin{array}{c}\text { Standardized } \\
\text { Coefficients }\end{array} \\
\text { Beta }\end{array}$} & \multirow[b]{2}{*}{$\mathbf{T}$} & \multirow[b]{2}{*}{ Sig. } \\
\hline & & \begin{tabular}{c|}
$\mathbf{B}$ \\
\end{tabular} & Std. Error & & & \\
\hline \multirow[t]{4}{*}{1} & (Constant) & 1744,035 & 613,077 & & 2,845 &, 005 \\
\hline & DER & $-176,472$ & 80,601 &,- 114 & $-2,189$ & 030 \\
\hline & CR & 13,878 & 1,097 &, 779 & 12,651 &, 000 \\
\hline & NPM & $-18,335$ & 12,189 &,- 095 & $-1,504$ &, 134 \\
\hline
\end{tabular}

a. Dependent Variable: Harga Saham

Based on the table it can be concluded as follows:

a. The Effect of Debt to Equity Ratio (DER) on Stock Prices Harga

The variable Debt to Equity Ratio has a t value of -2.189 and a significance value of 0.030 . The significance value $<0.05$, which means that the DER variable partially has a significant effect on the stock price variable.

b. Effect of Current Ratio on Stock Price

The Current Ratio variable has a t-count value of 12.651 and a significance value of 0.000 . The significance value $<0.05$, which means that the $\mathrm{CR}$ variable partially has a significant effect on the stock price variable. 
c. Effect of Net Profit Margin (NPM) on Stock Price

The Net Profit Margin variable has a $t$ value of -1.504 and a significance value of 0.134 . The significance value $>0.05$, which means that the NPM variable partially has no effect on the stock price variable.

\section{Multiple Linear Regression Analysis Test Results}

Multiple linear regression analysis was used to test the effect of two or more independent variables (explanatory) on the dependent variable (Ghozali, 2017). From the results of SPSS version 20, the following multiple linear regression equation was obtained:

Share Price $=1,744,035-176.472$ DER $+13,878$ CR $-18,335 \mathrm{NPM}+\mathrm{e}$

From the results of the multiple linear regression equation above, it can be concluded that:

a. The constant value of 1,744,035 means that if the variables Debt to Equity Ratio (DER), Earning Per Share (EPS), and Net Profit Margin (NPM) are 0, then the stock price will show a value of 1,744,035.

b. Debt to Equity Ratio (DER) variable regression coefficient of -176.472 shows a negative sign. This shows that DER has a negative effect on stock prices. This means that if the DER variable increases by one unit, then the stock price will decrease by 176.472 .

c. The regression coefficient of the Current Ratio variable of 13.878 shows a positive sign. This shows that CR has a positive effect on stock prices. This means that if the CR variable increases by one unit, then the stock price will increase by 13.878 .

d. The regression coefficient of the Net Profit Margin (NPM) variable is -18.335 which shows a negative sign. This shows that NPM has a negative effect on stock prices. This means that if the NPM variable increases by one unit, then the stock price will decrease by 18.335 .

\section{DISCUSSION}

\section{Effect of Debt to Equity Ratio (DER) on Stock Price}

Based on the results of the research conducted, it shows that DER has a negative and significant effect on stock prices. Thus, a high DER indicates that the company has a high risk so that it tends to be avoided by investors and results in decreased stock demand and triggers a decline in stock prices. And vice versa if the DER is low then the stock price will increase.

The results of this study are supported by the results of previous research conducted by Banchuenvijit (2016) which revealed that DER has a negative and significant effect on stock prices. The results are different from the research conducted by Ginting et al. (2017) which revealed that DER has no effect on stock prices because the study states that a high or low DER will not affect stock prices because if the company earns a profit, the company tends to use the profit to pay debts. rather than dividing dividends. So that an investor if he wants to invest in a company does not use DER as a consideration.

\section{Effect of Current Ratio (CR) on Stock Prices}

The results of statistical tests ( $\mathrm{t}$ test) show that the current ratio has a significant positive effect on stock prices. The results of this study are also supported by the results of research conducted by Rompas (2018). Therefore, the current ratio is a ratio used to measure the level of a company's ability to meet short-term financial obligations on time. A high level of liquidity reduces the company's failure to meet short-term financial obligations to creditors and vice versa. This will affect the interest of investors to invest their funds. The greater this ratio, the more efficient the company in utilizing the company's current assets. (Munawir, 2019).

The results of this study are supported by previous research conducted by Indriyani and Sudiartha (2017), Putra and Lestari (2016) which stated that company liquidity had a positive effect on stock prices. The results are different from the research conducted by Suwardika and Mustanda (2017), and Haryadi (2016) which states that company liquidity has no effect on firm value, because in this study it is stated that large or small company liquidity will not be able to affect company value. If you want to assess a company, you will not look at the company's liquidity which is reflected in the total assets of the company.

\section{Effect of Net Profit Margin (NPM) on Stock Prices Harga}

Based on the results of research conducted shows that NPM has no effect on stock prices. Thus, the higher the NPM does not provide confidence to investors to own the company's shares which will not affect the decrease or increase in stock prices in the future. Thus reducing the interest of investors to buy shares of the company. This shows that investors tend to pay less attention to NPM as a ratio that can be considered in their investment decisions.

The results of this study are supported by the results of previous research conducted by Hutasoit et al (2019) which revealed that NPM has no effect on stock prices. The results are different from the research 
conducted by Watung and Ilat (2016) which revealed that NPM has a significant influence on stock prices because the study stated that a high NPM will affect stock prices because if the company has the ability to generate profits, investors will be interested in buying shares. This will cause the stock price to rise. So that an investor if he wants to invest in a company uses NPM as a consideration.

\section{CONCLUSIONS AND SUGGESTIONS}

\section{Conclusion}

This study aims to examine and analyze the effect of Debt to Equity Ratio (DER), Current Ratio (CR) and Net Profit Margin (NPM) on stock prices of banking companies listed on the Indonesia Stock Exchange (IDX), with a sample data of 175 during the period. 2014 to 2018. Based on the results of the data analysis and discussion conducted, it can be concluded as follows:

1. Debt to Equity Ratio (DER) has a negative and significant effect on stock prices

2. Current Ratio (CR) has a positive and significant effect on stock prices

3. Net Profit Margin (NPM) has no effect on stock prices

\section{Suggestion}

Based on the research conducted, the results and conclusions have been described above, the suggestions that can be given are as follows:

1. For Academics

For further research, replace and use other variables other than those in the study. In addition, it would be better to use other samples in conducting research, so that this research can be generalized to all companies in Indonesia.

2. For Practitioners

For the company's management, it is better to always evaluate the company's performance by minimizing the DER ratio because the ideal DER is below 1 or below $100 \%$, so that investors are more confident to invest.

\section{REFERENCE}

1. Amalya, N. T. (2018). Pengaruh Return On Asset, Return On Equity, Net Profit Margin Dan Debt To Equity Ratio Terhadap Harga Saham. Jurnal Sekuritas (Saham, Ekonomi, Keuangan Dan Investasi), 1(3).

2. Aprilia, V. (2018). Pengaruh Current Ratio, Debt To Equity Ratio, Return On Asset, Total Asset Turnover, Dan Price Earning Ratio Terhadap Harga Saham (Studi Empiris Pada Perusahaan Properti Yang Terdaftar Pada Bursa Efek Indonesia Tahun 2012-2016) (Doctoral Dissertation, Universitas Mercu Buana Jakarta).

3. Apsara, R. H., \& Indriani, A. (2017). Analisis Pengaruh Crude Oil Price, Earning Per Share, Price To Book Value, Return On Assets Dan Debt To Equity Ratio Terhadap Harga Saham (Perusahaan Sub Sektor Batubara Yang Terdaftar Di Bursa Efek Indonesia Periode 2012-2016) (Doctoral Dissertation, Fakultas Ekonomika Dan Bisnis).

4. Asmirantho, E., \& Yuliawati, E. (2015). Pengaruh Dividen Per Share (DPS), Dividen Payout Ratio (DPR), Price To Book Value (PBV), Debt To Equity Ratio (DER), Net Profit Margin (NPM) Dan Return On Asset (ROA) Terhadap Harga Saham Pada Perusahaan Manufaktur Sub Sektor Makanan Dan Minuman Dalam Kemasan Yang Terdaftar Di BEI. JIAFE (Jurnal Ilmiah Akuntansi Fakultas Ekonomi), 1(2), 95-117.

5. Banchuenvijit, W. (2016). Financial Ratios And Stock Prices: Evidence From The Agriculture Firms Listed On The Stock Exchange Of Thailand. Utcc International Journal Of Business \& Economics, 8(2), 23-29.

6. Bintara, R., Tanjung P. R. S. (2019). Analysis of Fundamental Factors on Stock Return, International Journal of Academic Research in Accounting, Finance and Management Sciences 9 (2): 49-64

7. Bintara, R., Tanjung P. R. S. (2019). Analysis of Fundamental Factors on Stock Return, International Journal of Academic Research in Accounting, Finance and Management Sciences 9 (2): $49-64$

8. Cahyani, I. (2018). Pengaruh Current Ratio (CR), Return On Asset (ROA), Net Profit Margin (NPM) Dan Total Asset Turnover (TATO) Terhadap Harga Saham (Studi Empiris Pada Perusahaan Sub Sektor Batu Bara Yang Terdaftar Di Bursa Efek Indonesia Periode 2012-2016)(Doctoral Dissertation, Universitas Mercu Buana Jakarta).

9. Cahyaningrum, Y. W., \& Antikasari, T. W. (2017). Pengaruh Earning Per Share, Price To Book Value, Return On Asset, Dan Return On Equity Terhadap Harga Saham Sektor Keuangan. Jurnal Economia, 13(2), 191-200.

10. Dissanayake, T. D. S. H., \& Biyiri, E. (2017). The Impact Of Internal Factors On Share Price: Reference To Hotel Industry In Colombo Stock Exchange. Business And Management Research Journal, 7(3), 33-37.

11. Fitriantono, Y. (2018). Pengaruh Price Book Value, Earning Per Share, Return On Asset Dan Debt To Equity Ratio Terhadap Harga Saham (Pada Emiten LQ 45 di Bursa Efek Indonesia) (Doctoral Dissertation, Universitas Mercu Buana Jakarta).

12. Ghozali, I. (2018). Aplikasi Analisis Multivariate Dengan Program IBM SPSS 25. Semarang: Badan Penerbit Universitas Diponegoro

13. Ginting, P., \& Munthe, K. (2017). Pengaruh Debt To Equity Ratio, Dan Earning Per Share Terhadap Harga Saham Pada Perusahaan Manufaktur Yang Go Public Di Bursa Efek Indonesia. Jurnal Manajemen Dan 
Bisnis, 17(1), 96-107.

14. Gustmainar, J., \& Mariani, M. (2018). Analisis Pengaruh Current Ratio, Debt To Equity Ratio, Gross Profit Margin, Return On Investment, Dan Earning Per Share Terhadap Harga Saham Pada Perusahaan LQ 45 Yang Terdaftar Di Bursa Efek Indonesia Tahun 2010-2016. Bilancia: Jurnal Ilmiah Akuntansi, 2(4), 465-476.

15. Hidayah, Nurul (2015) Pengaruh Investment Opportunity Set (IOS) dan Kepemilikan Manajerial Terhadap Nilai Perusahaan pada Perusahaan Property dan Real Estat di Bursa Efek Indonesia. Jurnal Akuntansi/Volume XIX, No. 03, September 2015: 420-432

16. Hidayah, Nurul (2015) Pengaruh Investment Opportunity Set (IOS) dan Kepemilikan Manajerial Terhadap Nilai Perusahaan pada Perusahaan Property dan Real Estat di Bursa Efek Indonesia. Jurnal Akuntansi/Volume XIX, No. 03, September 2015: 420-432

17. Hidayatullah, H., \& Indriani, A. (2018). Analisis Pengaruh Return On Asset, Debt To Equity Ratio, Current Ratio, Price To Book Value Terhadap Harga Saham (Studi Kasus Pada Perusahaan Manufaktur Yang Terdaftar Di BEI Periode 2012-2016) (Doctoral Dissertation, Fakultas Ekonomika Dan Bisnis).

18. Hutasoit, P. L., Sinaga, C., Marbun, R., Sembiring, S. A. T., \& Sinaga, J. B. L. A. (2019). Pengaruh Net Profit Margin, Non Performing Loan Dan Capital Adequacy Ratio Terhadap Harga Saham Pada Perusahaan Perbankan Yang Terdaftar Di Bursa Efek Indonesia Periode 2014-2017. Aksara Public, 3(2), 120-133.

19. Indriani, N. P. L., \& Dewi, S. K. S. (2016). Pengaruh Variabel Tingkat Kesehatan Bank Terhadap Harga Saham Perbankan Di Bursa Efek Indonesia. E-Jurnal Manajemen Universitas Udayana, 5(5).

20. Ismail, F. (2018). Statistika Untuk Penelitian Pendidikan Dan Ilmu-Ilmu Sosial. Jakarta: Kencana

21. Kurniawan, R. (2016). Analisis Regresi. Jakarta: Prenada Media

22. Manan, A. (2015). Aspek Hukum Dalam Penyelenggaraan Investasi Di Pasar Modal Syariah.Jakarta: Prenada Media

23. Maulana, F. (2014). Analisis Pengaruh Kinerja Keuangan Terhadap Harga Saham Pada Perusahaan Makanan dan Minuman Yang Terdaftar di BEI Periode Tahun 2010-2012.

24. Nainggolan, A. (2019). Pengaruh EPS, ROE, NPM, DER, PER Terhadap Harga Saham Pada Perusahaan Perbankan Yang Terdaftar Di Bursa Efek Indonesia Periode 2014-2017. Jurnal Manajemen, 5(1), 61-70.

25. Nur'aidawati, S. (2018). Pengaruh Current Ratio (CR), Total Asset Turnover (TATO), Debt To Equity Ratio (DER) Dan Return On Asset (ROA) Terhadap Harga Saham Dan Dampaknya Pada Nilai Perusahaan (Studi Kasus Pada Sepuluh Bank Terbesar Yang Terdaftar Di Bursa Efek Indonesia Periode Tahun 2011-2015). Jurnal Sekuritas (Saham, Ekonomi, Keuangan Dan Investasi), 1(3).

26. Oktania, F. (2018). Pengaruh Book Value Equity Per Share, Devidend Per Share Dan Net Profit Margin Terhadap Harga Saham Sektor Pertambangan Yang Terdaftar Di BEI Periode 2013-2016 (Doctoral Dissertation, Universitas Mercu Buana Jakarta).

27. Oktavian, R. (2019). Pengaruh Earning Per Share (EPS) Dan Dividen Per Share (DPS) Terhadap Harga Saham PT Wijaya Karya (Persero) Tbk. Jurnal Sekuritas (Saham, Ekonomi, Keuangan Dan Investasi), 2(2), 156-171.

28. Purnomo, R.A. (2016). Analisis Statistik Ekonomi Dan Bisnis Dengan Spss. Ponorogo: Wade Group

29. Putra, A. S. (2018). Pengaruh Earning Per Share (EPS), Dividend Per Share (DPS) Dan Financial Leverage (FL) Terhadap Harga Saham Perusahaan Manufaktur Di Bursa Efek Indonesia. Jurnal Ecogen, 1(1), 169-175.

30. Rusnaeni-Rusnaeni, N. (2017). Pengaruh Earning Per Share (EPS) Dan Dividend Per Share (DPS) Terhadap Harga Saham Pada PT. Adhi Karya (Persero) Tbk Dan PT. Total Bangunan Persada Tbk. Jurnal Sekuritas (Saham, Ekonomi, Keuangan Dan Investasi), 1(2).

31. Sapariyah, R. A., Khristiana, Y., \& Juwanto, J. (2017). Return On Asset, Debt To Equity Ratio, Price Earning Ratio, Kurs Dan Inflasi Terhadap Harga Saham. Advance, 4(1), 1-9.

32. Sari, P. (2015). Pengaruh Current Ratio, Net Profit Margin, Return On Assets, Debt To Equity Ratio, Total Assets Turnover Dan Earning Per Share Terhadap Harga Saham (Studi Pada Perusahaan Industri Barang Konsumsi Yang Go Public Di Bursa Efek Indonesia Pada Periode Tahun 2010-2013). Tanjung Pinang: Universitas Maritim Raja Ali Haji Tanjungpinang.

33. Septiandri, V. (2019). Analisis DER, EPS, ROA, Inflasi Dan Suku Bunga SBI Terhadap Harga Saham Perusahaan Yang Terdaftar Pada Jakarta Islamic Index (Doctoral Dissertation, Universitas Mercu Buana Jakarta).

34. Sha, T. L. (2015). Pengaruh Kebijakan Dividen, Likuiditas, Net Profit Margin, Return On Equity, Dan Price To Book Value Terhadap Harga Saham Pada Perusahaan Manufaktur Yang Terdaftar Di Bursa Efek Indonesia 2010-2013. Jurnal Akuntansi, 19(2), 276-294.

35. Sitanggang, J.P. (2014). Manajemen Keuangan Perusahaan Ed.2. Jakarta: Mitra Wacana Media

36. Sugiono, A., \& Untung, E. (2016). Aspek Panduan Praktis Dasar Analisa Keuangan Edisi Revisi. Jakarta: Gramedia Widiasarana

37. Talamati, M. R., \& Pangemanan, S. S. (2015). The Effect Of Earnings Per Share (EPS) \& Return On Equity (ROE) On Stock Price Of Banking Company Listed In Indonesia Stock Exchange (IDX) 2010-2014. Jurnal Emba: Jurnal Riset Ekonomi, Manajemen, Bisnis Dan Akuntansi, 3(2).

38. Tanjung, P.R.S., Wahyudi, S.M. (2019). Analysis the Effect Disclosure of Sustainability Report, Economic Value Added and Other Fundamental Factors of Companies on Company Value, International Journal of Academic

39. Utami, A. T., \& Herlambang, L. (2016). Pengaruh Variabel Makro Ekonomi Terhadap Indeks Jakarta Islamic Index (JII) Periode Januari 2010 Hingga November 2015. Jurnal Ekonomi Syariah Teori Dan Terapan, 3(1), 70.

40. Velankar, N., Chandani, A., \& Ahuja, A. K. (2017). Impact Of EPS And DPS On Stock Price: A Study Of Selected Public Sector Banks Of India. Prestige International Journal Of Management \& It-Sanchayan, 6(1), 111-121.

41. Wangarry, A. R., Poputra, A. T., \& Runtu, T. (2016). Pengaruh Tingkat Return On Investment (ROI), Net Profit 
Margin (NPM), Dan Debt To Equity Ratio (DER) Terhadap Harga Saham Perbankan Di Bursa Efek Indonesia (BEI). Jurnal Emba: Jurnal Riset Ekonomi, Manajemen, Bisnis Dan Akuntansi, 3(4).

42. Watung, R. W., \& Ilat, V. (2016). Pengaruh Return On Asset (ROA), Net Profit Margin (NPM), Dan Earning Per Share (EPS) Terhadap Harga Saham Pada Perusahaan Perbankan Di Bursa Efek Indonesia Periode 2011 2015. Jurnal Emba: Jurnal Riset Ekonomi, Manajemen, Bisnis Dan Akuntansi, 4(2).

43. Windarsih, S. Y. (2018). Analisis Pengaruh Return On Equity Dan Debt To Equity Ratio Terhadap Harga Saham (Studi Kasus Pada Perusahaan Pertambangan Yang Terdaftar Di Bursa Efek Indonesia Tahun 20122016) (Doctoral Dissertation, Universitas Mercu Buana Jakarta). 